\title{
EVALUATION ON FACTORS AFFECTING BACTERIA GROWTH IN COLLECTED RAINWATER
}

\author{
Nureleana H. Sarudu ${ }^{1}$, Onni S. Selaman ${ }^{2}$, Rubiyah Baini ${ }^{3}$ and Nor Azalina Rosli ${ }^{4}$ \\ 1,2,4 Department of Civil Engineering, Faculty of Engineering, Universiti Malaysia Sarawak \\ ${ }^{3}$ Department of Chemical Engineering and Energy Sustainability ,Faculty of Engineering, Universiti Malaysia Sarawak
}

Date received: 14/08/2015, Date accepted: 25/08/2015

Corresponding author's email: sosuhaiza@feng.unimas.my

\begin{abstract}
Rainwater collected in rural areas may be contaminated and could affect health if consumed. Therefore, the rainwater quality is evaluated by identifying factors that affect the growth of bacteria and how they contribute to the growth. The factors are temperature, $\mathrm{pH}$, oxygen and nutrient concentration which tested using thermometer, $\mathrm{pH}$ meter, DO meter and TOC Analyser. Bacteria densities were determined through MPN method using Colilert-18. Results showed Kuching samples have lower water temperature and TOC, less acidic but higher DO compared to Kota Samarahan samples. Evening samples showed lower water temperature and DO, but higher acidity and TOC compared to morning samples. Bacteria densities also showed decrease in readings and only Total Coliform are presence as rainwater collected in an open space. Samples temperature between $26^{\circ} \mathrm{C}$ and $28^{\circ} \mathrm{C}$ and pH readings between 5.59 and 6.05 shows that bacteria may adapt and exhibit growth but limited. DO and TOC also decreases between $0.33 \mathrm{mg} / \mathrm{L}$ and $0.72 \mathrm{mg} / \mathrm{L}$ and between $0.6340 \mathrm{mg} / \mathrm{L}$ and $1.9338 \mathrm{mg} / \mathrm{L}$ respectively. This indicates the uptake of oxygen and usage of organic carbon by the bacteria. These results correspond to the decreasing bacteria densities as due to limitation of oxygen and nutrients concentration and ideal range of temperature and $\mathrm{pH}$ for growth.
\end{abstract}

Keywords: rainwater quality, rainwater harvesting, bacteria growth, bacteria densities

\subsection{INTRODUCTION}

SINCE ancient times, rainwater has been collected and stored in tanks or any other types of storage

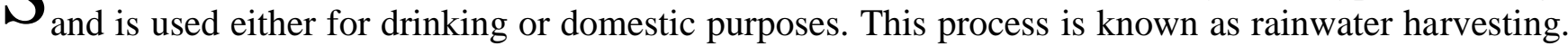
It is very convenient mainly for people living in rural areas. However, the financial ability of a household in rural areas is very limited in which suitable storage such as concrete tank, cannot be afforded. Under these circumstances, rainwater harvesting by using low cost storage tank such as jars is more appropriate for the families [1]. These factors however, raise the concern of the quality of rainwater collected. The quality of the rainwater harvested solely depends on the area where it is collected, topography, conditions of the weather at the time of collection and the type of handling and controlling of rainwater [2].

The quality of rainwater can be degraded and may lead to potential health risks due to chemical and microbiological factors [3][4]. Rainwater may subject to chemical contamination such as from traffic emissions, industrial pollutions and agricultural usage of fertilizers and pesticides [2]. In terms of microbiological factors, such as pathogens, which is a disease-producing agent that are mainly found in the birds', mammals' and reptiles' wastes could exist in the rainwater. This in return could cause effect on health if consumed.

The main concern on the quality of harvested rainwater is in the rural areas. When the societies harvest rainwater, they usually do not check on the quality of the rainwater. It is very common for them to directly use the stored rainwater as they assumed that the rainwater is safe to be used. As for consumption usage such as for drinking and cooking, usually they would first boil the harvested rainwater before intake and whenever there is new rainfall, they usually emptied the remaining rainwater collected from the storage tank and then restored the freshly harvested rainwater. This process that has been mentioned shows how the harvested rainwater is being used and managed traditionally. 
However, this does not indicate that the quality of harvested rainwater is free from any contamination. It could be exposed to any other types of contamination either from air pollution or even birds wastes. Therefore, this study is to analyse the quality of the rainwater through the growth of bacteria in which by identifying the factors that is affecting the bacteria growth and how they contribute to the growth in the raw harvested rainwater.

\subsection{METHODOLOGY}

In this study, rainwater is collected from Kuching and Kota Samarahan areas in which the samples are grouped into two categories. Rainwater Group I consist of rainwater that is collected from both Kuching $(\mathrm{KCH} 1)$ and Kota Samarahan (KS1) areas in which the rainwater was collected during night time on the same day. Rainwater Group II on the other hand consist of rainwater collected only from Kota Samarahan area but at different time of collection, that is, one was collected in the evening (KS2) and the other was collected near midnight to the next early morning (KS3). The method used to collect the rainwater samples is by using buckets and beakers which are placed in an open space. The samples are then used to conduct laboratory experiments in which Rainwater Group I samples are tested up to 30 days, while Rainwater Group II samples are tested up to 20 and 15 days for KS2 and KS3 sample respectively. The testing period differs as due to the time of collection of the rainwater. The testing period for Group I samples is fixed for 30 days. However, Rainwater Group II samples are tested up to the days mentioned but ends at the same time as the results shows constant readings, meaning there are only slight changes based on the results obtained throughout the testing period.

The factors that contribute to the growth of bacteria are temperature, $\mathrm{pH}$, oxygen concentration and nutrient concentration. These factors are analysed through laboratory testing in which the rainwater collected is tested by using thermometer for temperature, $\mathrm{pH}$ meter for $\mathrm{pH}$, Do meter for oxygen concentration and TOC Analyser for nutrient concentration. In order to relate the factors to the growth of bacteria, the bacteria densities are determined through the Most Probable Number (MPN) method which is based on the Defined Substrate Technology (DST) using Colilert-18 and Quanti-Tray (IDEXX) whereby it can detect E. coli and Total Coliform bacteria.

\subsection{RESULTS AND ANALYSIS}

\subsection{Bacteria Density}

KS1 and KS2 samples were tested to determine the bacteria densities in the collected rainwater samples where KS1 sample was tested with no dilutions while KS2 sample was tested with dilutions. The results obtained from KS1 sample which were tested on Day 2 showed positive yellow wells for all the 51 wells of the Quanti-Trays when tested. This indicates positive results for total coliform bacteria. While, no E. coli bacteria was found under the UV lamp. However, when all the wells showed positive results, the value of bacteria contain based from the MPN table are to be more than 200.5MPN/100mL. Same results were obtained when tested on Day 9 and 15. This shows that no exact count can be obtained when no dilution is being made as there exist too many bacteria in the samples in order to get the accurate bacteria densities [5].

KS2 sample on the other hand was tested with dilution factor of 1:100 and 1:10. The first test was done on Day 4 with a 1:100 dilution factor while Day 7, 12 and 18 were tested with a dilution factor of 1:10. The results also showed that only total coliforms bacteria is presence while there is no E. coli exist when tested under the UV lamp. This shows that the rainwater collected are free from faecal contamination. The results obtained from KS2 sample are shown in Table 1. As throughout the testing period from Day 4 to 18, it can be seen that the bacteria densities decreases throughout the time the sample is being tested. Based from all the samples tested, only total coliforms bacteria showed positive results. This may due to method of sampling whereby the rainwater samples are collected in an open 
space.

Table 1 Bacteria Densities Obtained from KS2 Sample

\begin{tabular}{|c|c|c|c|c|c|c|c|}
\hline \multirow{2}{*}{ Day } & \multirow{2}{*}{$\begin{array}{l}\text { Dilution } \\
\text { Factor }\end{array}$} & \multicolumn{2}{|c|}{ Total Coliform } & \multicolumn{2}{|c|}{ E.Coli } & \multicolumn{2}{|c|}{$\begin{array}{c}\text { Density of Bacteria } \\
\text { (MPN/100mL) }\end{array}$} \\
\hline & & $\begin{array}{c}\text { (No. of +ve } \\
\text { wells) }\end{array}$ & MPN & $\begin{array}{c}\text { (No. of +ve } \\
\text { wells) }\end{array}$ & MPN & Total Coliform & E. coli \\
\hline 4 & $1: 100$ & 14 & 16.4 & 0 & 0 & 1640 & 0 \\
\hline 7 & $1: 10$ & 42 & 88.5 & 0 & 0 & 885 & 0 \\
\hline 12 & $1: 10$ & 35 & 59.1 & 0 & 0 & 591 & 0 \\
\hline 18 & $1: 10$ & 21 & 27.1 & 0 & 0 & 271 & 0 \\
\hline
\end{tabular}

\subsection{Temperature}

All the samples were tested for their initial rainwater temperature readings and also throughout the testing period. Kuching sample $(\mathrm{KCH} 1)$ showed an initial rainwater temperature of $27^{\circ} \mathrm{C}$ while Kota Samarahan sample (KS1) showed an initial rainwater temperature of $28^{\circ} \mathrm{C}$. This shows that Kota Samarahan sample temperature is higher than Kuching sample. For KS2 sample, the rainwater which is collected in the evening showed an initial water temperature of $26^{\circ} \mathrm{C}$ while KS3 sample which is collected in the morning showed an initial water temperature of $27^{\circ} \mathrm{C}$. When comparing based on the initial readings of the time of collection from the results obtained, this shows that morning samples temperature is higher than the evening samples.

Throughout the testing period for all the samples, $\mathrm{KCH} 1$ and $\mathrm{KS} 1$ sample showed a decrease reading from initial readings before it fluctuates throughout the testing period in which it ranges from $24^{\circ} \mathrm{C}$ to $27^{\circ} \mathrm{C}$ and from $24^{\circ} \mathrm{C}$ to $28^{\circ} \mathrm{C}$ respectively. While for KS2 and KS3 samples, both the temperature of the samples fluctuates throughout the testing period in which it ranges from $26^{\circ} \mathrm{C}$ to $28.8^{\circ} \mathrm{C}$.

Based on results obtained, we can conclude that the samples temperature readings differ when collected at different areas and at different time of collection. The variation of the initial readings for all the samples may due to the rainwater samples being subjected to surrounding temperature conditions at the time of collection. The time when the temperature of the samples is being measured also may affect the initial readings of the samples. As for throughout the testing period, the variation of the samples temperature over time may due to the rainwater samples being subjected to different temperature, for example, based on the weather condition when the samples are stored at room temperature. In terms of bacteria growth, every organism has an optimal, minimum and maximum growth temperature [5][6]. Organisms can grow the most, at limited and even dies depending on the temperature it is subjected to. Non-fecal coliform bacteria on the other hand can grow at an elevated temperature [7]. This concludes that certain bacteria have a certain range of ideal temperature for it to grow at maximum rate.

\section{$3.3 \mathrm{pH}$}

All the samples were tested for their initial $\mathrm{pH}$ readings and also throughout the testing period. Kuching sample (KCH1) showed initial pH level of 6.05 while Kota Samarahan sample (KS1) showed a pH level of 5.83. This shows that the $\mathrm{pH}$ level for Kota Samarahan sample is slightly acidic than Kuching sample. For KS2 sample, the rainwater which is collected in the evening showed an initial pH level of 5.59 while KS3 sample which is collected in the morning showed an initial pH level of 5.72. When comparing based on the initial readings from the results mentioned, this shows that the sample collected in the evening is slightly acidic when compared to morning sample.

Throughout the testing period for all the samples, $\mathrm{KCH} 1$ and $\mathrm{KS} 1$ samples showed a gradual increase in $\mathrm{pH}$ meaning more alkaline throughout the testing period in which it ranges between 5.96 and 7.35 and 
between 5.83 and 7.26 respectively. KS2 and KS3 samples showed the same results where there is also gradual increase in $\mathrm{pH}$ in which it ranges between 5.59 and 6.79 for KS2 sample and between 5.72 and 6.53 for KS3 sample.

Based on the results, all the rainwater collected are slightly acidic. Kota Samarahan (KS1) sample showed more acidic than Kuching (KCH1) sample while KS2 sample collected in the evening also showed more acidic than KS3 sample which is collected in the morning. The rainwater is slightly acidic due to the water vapour mixed with the atmospheric carbon dioxide which later produces carbonic acid [8][9]. Even though it is a weak acid, it lowers the $\mathrm{pH}$ levels of the rainwater. One of the reason in which there is a variation in the $\mathrm{pH}$ value may due to the living organism that exist. The balance of acids and bases tend to change when the organisms consumed the nutrients, undergo chemical reactions and eliminate wastes [5]. Therefore it fluctuate the $\mathrm{pH}$ readings. Mostly bacteria grow at its best at $\mathrm{pH}$ near neutral that is between 6.5 and 7.5. However, most organisms also found to exhibit microbial growth in $\mathrm{pH}$ between 4.0 and 8.0 [10].

\subsection{Dissolved Oxygen (DO)}

All the samples were tested for their initial DO readings and also throughout the testing period. Kuching sample (KCH1) showed initial DO concentration of $5.67 \mathrm{mg} / \mathrm{L}$ while Kota Samarahan sample (KS1) showed a DO concentration of $5.42 \mathrm{mg} / \mathrm{L}$. This shows that the DO concentration for Kuching sample is slightly higher than Kota Samarahan sample. For KS2 sample, the rainwater which is collected in the evening showed an initial DO concentration of $5.21 \mathrm{mg} / \mathrm{L}$ while KS3 sample which is collected in the morning showed an initial DO concentration of $5.38 \mathrm{mg} / \mathrm{L}$. When comparing based on the initial readings from the results mentioned, this shows that the sample collected in the morning has slightly higher DO concentration when compared to evening sample.

Throughout the testing period, all the samples showed a drop in readings from initial readings before it fluctuates throughout the testing period. KCH1 sample readings showed a drop up to Day 9 while KS1 sample showed a drop up to Day 11 from initial readings. Throughout the testing period of DO concentration for $\mathrm{KCH} 1$ sample, it ranges between $4.90 \mathrm{mg} / \mathrm{L}$ and $5.67 \mathrm{mg} / \mathrm{L}$ while for $\mathrm{KS} 1$ sample; it ranges between $4.91 \mathrm{mg} / \mathrm{L}$ and $5.42 \mathrm{mg} / \mathrm{L}$. For KS2 sample, readings showed a drop up to Day 5 and the range of DO concentration is between $4.68 \mathrm{mg} / \mathrm{L}$ and $6.79 \mathrm{mg} / \mathrm{L}$ throughout the testing period. While for KS3 sample, readings showed a drop up to Day 7 and the range of DO concentration is between $4.66 \mathrm{mg} / \mathrm{L}$ and $5.38 \mathrm{mg} / \mathrm{L}$ throughout the testing period.

Based on all the results obtained, this showed that the Kuching (KCH1) sample have a slightly higher dissolved oxygen concentration compared to Kota Samarahan (KS1) sample. While in terms of time collection, rainwater collected in the morning showed more dissolved oxygen concentration than the evening sample. This result correspond to that when the water temperature is high, in which for this study is in the evening, there is a decrease in dissolved oxygen availability [11]. This also shows that different areas and different time of collection of rainwater samples have different DO concentration. The variation of DO concentration on the other hand, may due to oxygen becoming the growth limiting factor in many aquatic environments [12]. Microorganisms also grouped based on their requirement of oxygen. Total coliform bacteria can be categorized as aerobic or facultative anaerobic bacteria in terms of oxygen concentration [13]. Aerobic organisms undergo respiration process to produce energy which uses up the oxygen concentration [10]. This shows that the growth of bacteria can be measured by oxygen uptake [14]. Therefore, this can conclude that the DO concentration decreases as due to the bacteria activities in which for it to produce energy.

\subsection{Total Organic Carbon (TOC)}

All the samples were tested for their initial TOC readings and also throughout the testing period. Kuching sample (KCH1) showed initial TOC concentration of $1.944 \mathrm{mg} / \mathrm{L}$ while Kota Samarahan sample (KS1) showed a TOC concentration of $2.542 \mathrm{mg} / \mathrm{L}$. This shows that the TOC concentration for 
Kuching sample is lower than Kota Samarahan sample. For KS2 sample, the rainwater which is collected in the evening showed an initial TOC concentration of $2.290 \mathrm{mg} / \mathrm{L}$ while KS3 sample which is collected in the morning showed an initial TOC concentration of $0.9833 \mathrm{mg} / \mathrm{L}$. When comparing based on the initial readings from the results mentioned, this shows that the sample collected in the morning has lower TOC concentration when compared to evening sample.

Throughout the testing period, all the samples showed a drop in readings from initial readings before it fluctuates throughout the testing period. Both $\mathrm{KCH} 1$ and $\mathrm{KS} 1$ samples readings showed a drop up to Day 8 from initial readings. Throughout the testing period of TOC concentration for $\mathrm{KCH} 1 \mathrm{sample}$, it ranges between $0.6905 \mathrm{mg} / \mathrm{L}$ and $1.944 \mathrm{mg} / \mathrm{L}$ while for KS1 sample it ranges between $0.2888 \mathrm{mg} / \mathrm{L}$ and $2.542 \mathrm{mg} / \mathrm{L}$. For KS2 sample, readings showed a drop up to Day 7 and the range of TOC concentration is between $1.133 \mathrm{mg} / \mathrm{L}$ and $2.290 \mathrm{mg} / \mathrm{L}$ throughout the testing period. While for KS3 sample, readings also showed a drop up to Day 7 and the range of TOC concentration is between $0.3251 \mathrm{mg} / \mathrm{L}$ and $0.9833 \mathrm{mgL}$ throughout the testing period.

Based on all the results obtained, Kota Samarahan (KS1) sample showed a higher TOC concentration than Kuching $(\mathrm{KCH} 1)$ sample. In terms of time collection, KS2 sample which is collected in the evening showed higher TOC concentration than KS3 sample. This shows that different areas and different time of collection of rainwater have different TOC concentration. The variation of TOC concentration throughout the testing period on the other hand, may due to bacteria activity, in which it consumed the nutrients (TOC) obtained from the natural environment for cell growth or cellular activities [12]. Low nutrient conditions are commonly occur in the natural environments [15]. Total coliforms are categorized as copiotrophic bacteria but are able to grow under oligotrophic conditions [16]. Since the principal nutrient for growth of coliform bacteria is organic carbon [17][18], this shows that the bacteria consumed the nutrients for growth which in return, lowers the TOC concentration [19]. Therefore, these can conclude that the decreases in TOC concentration of the samples are due to the bacteria which consumed nutrients for growth.

\subsection{Result Summary}

In the analyses, the rainwater collected at different areas and time which the rainwater is collected showed that it influences the temperature, $\mathrm{pH}$, dissolved oxygen and total organic carbon concentration. Based on the results, rainwater which is collected from Kuching areas showed lower water temperature and TOC concentration, less acidic but more in DO concentration as compared to rainwater collected in the Kota Samarahan areas. In terms of time of collection, sample which is collected in the evening showed lower water temperature and DO concentration but higher in acidity and TOC concentrations when compared to rainwater collected in the morning. The results are summarised as shown in Table 2, Table 3 and Table 4.

Table 2 Sample Collected at the Same Time but at Different Places

\begin{tabular}{|c|c|c|c|c|c|}
\hline Sample & Similarity & Difference & Tests & Initial Reading & Comparison \\
\hline a)KCH1 & Time of & Area & Temperature $\left({ }^{\circ} \mathrm{C}\right)$ & a) 27 & $\mathrm{KCH} 1$ value is \\
\hline \multirow[t]{7}{*}{ b)KS1 } & collection & a)Kuching & & b) 28 & lower than KS1 \\
\hline & & b)Kota & $\mathrm{pH}$ & a) 6.05 & $\mathrm{KCH} 1$ is less \\
\hline & & Samarahan & & b) 5.83 & acidic than $\mathrm{KS} 1$ \\
\hline & & & $\mathrm{DO}(\mathrm{mg} / \mathrm{L})$ & a) 5.67 & $\mathrm{KCH} 1$ value is \\
\hline & & & & b) 5.42 & higher than KS1 \\
\hline & & & TOC (mg/L) & a) 1.944 & $\mathrm{KCH} 1$ value is \\
\hline & & & & b) 2.542 & lower than KS1 \\
\hline
\end{tabular}


Table 3 Sample Collected at the Same Place but Different Time

\begin{tabular}{llllll}
\hline Sample & Similarity & Difference & Tests & Initial Reading & Comparison \\
\hline a)KS2 & Area & Time of & Temperature $\left({ }^{\circ} \mathrm{C}\right)$ & a) 26 & KS2 value is \\
b)KS3 & & & b) 27 & lower than KS3 \\
& & & a) 5.59 & KS2 is more \\
& & & b) Evening & pH 5.72 & acidic than $\mathrm{KS} 3$ \\
& & & DO $(\mathrm{mg} / \mathrm{L})$ & a) 5.21 & KS2 value is \\
& & TOC $(\mathrm{mg} / \mathrm{L})$ & a) 2.290 & KS2 value is
\end{tabular}

Table 4 Samples Range of Readings throughout Testing Period

\begin{tabular}{|c|c|c|c|c|c|c|}
\hline Sample & Tests & $\begin{array}{c}\text { Initial } \\
\text { Readings }\end{array}$ & $\begin{array}{l}\text { Readings } \\
\text { Range }\end{array}$ & $\begin{array}{l}\text { Drop } \\
\text { Days }\end{array}$ & $\begin{array}{c}\text { Value of } \\
\text { Drop }\end{array}$ & Variation in Readings \\
\hline a)KCH1 & Temperature & a) 27 & a) $24-27$ & - & - & Samples being subjected to \\
\hline b)KS1 & $\left({ }^{\circ} \mathrm{C}\right)$ & b) 28 & b) $24-28$ & & & surrounding temperature \\
\hline c)KS2 & & c) 26 & c) $26-28.8$ & & & conditions at the time of \\
\hline \multirow[t]{16}{*}{ d)KS3 } & & d) 27 & d) $26-28.8$ & & & collection and the time when \\
\hline & & & & & & samples are being measured. \\
\hline & $\mathrm{pH}$ & a) 6.05 & a) $5.96-7.35$ & - & - & The balance of acids and \\
\hline & & b) 5.83 & b) $5.83-7.26$ & & & bases tend to change when \\
\hline & & c) 5.59 & c) $5.59-6.79$ & & & the organisms consumed the \\
\hline & & d) 5.72 & d) $5.72-6.53$ & & & nutrients, undergo chemical \\
\hline & & & & & & reactions and eliminate \\
\hline & & & & & & wastes. \\
\hline & $\mathrm{DO}(\mathrm{mg} / \mathrm{L})$ & a) 5.67 & a) $4.90-5.67$ & Day 9 & a) 0.63 & Oxygen becoming the \\
\hline & & b) 5.42 & b) $4.91-5.42$ & Day 11 & b) 0.51 & growth limiting factor for \\
\hline & & c) 5.21 & c) $4.68-6.79$ & Day 5 & c) 0.33 & the living organism that \\
\hline & & d) 5.38 & d) $4.66-5.38$ & Day 7 & d) 0.72 & $\begin{array}{l}\text { exists in the collected } \\
\text { rainwater. }\end{array}$ \\
\hline & TOC (mg/L) & a) 1.944 & a) $0.690-1.944$ & Day 8 & a) 1.018 & Bacteria consume nutrients \\
\hline & & b) 2.542 & b) $0.288-2.542$ & Day 8 & b) 1.9338 & (TOC) obtained from the \\
\hline & & c) 2.290 & c) $1.133-2.290$ & Day 7 & c) 1.074 & natural environment for cell \\
\hline & & d) 0.9833 & d) $0.325-0.983$ & Day 7 & d) 0.634 & growth or cellular activities. \\
\hline
\end{tabular}

The raw harvested rainwater results samples are also compared to the Drinking Water Quality Standards in terms of bacteriological quality. The acceptable value of Total Coliform bacteria is to be 5000 MPN/100ml for the recommended raw water quality as stated in Table 5 [20]. When compared to the harvested rainwater collected for this research, the initial value of Total Coliform is $1640 \mathrm{MPN} / 100 \mathrm{ml}$. Therefore, there will only be minimal treatment for the raw rainwater collected as it conform to the standards [20][21]. As for the drinking water quality standard, it is mentioned that the Total Coliform and E. coli bacteria must not be detected in any 100ml sample [20]. Since there is no E. coli found in the collected rainwater, it conforms to the standards [20]. However, the presents of Total Coliform in 
the collected rainwater does not conform to the standards. This shows that the raw rainwater collected is not drinkable since Total Coliform is present.

Table 5 Guidelines on National Standard for Drinking Water Quality [20]

\begin{tabular}{lccc}
\hline & & $\begin{array}{c}\text { Recommended } \\
\text { Raw Water Quality }\end{array}$ & $\begin{array}{c}\text { Drinking } \\
\text { Parameter }\end{array}$ \\
\cline { 3 - 3 } & Group & $\begin{array}{c}\text { Acceptable Value (mg/litre } \\
\text { (unless otherwise stated) })\end{array}$ & $\begin{array}{c}\text { Maximum Acceptable } \\
\text { Value (mg/litre (unless } \\
\text { otherwise stated) }\end{array}$ \\
\hline Total Coliform & 1 & $5000 \mathrm{MPN} / 100 \mathrm{ml}$ & 0 in $100 \mathrm{ml}$ \\
E.Coli & 1 & $5000 \mathrm{MPN} / 100 \mathrm{~m}$ & 0 in $100 \mathrm{~m}$ \\
Turbidity & 1 & $1000 \mathrm{NTU}$ & $5 \mathrm{NTU}$ \\
Color & 1 & $300 \mathrm{TCU}$ & $15 \mathrm{NTU}$ \\
pH & 1 & $5.5-9.0$ & $6.5-9.0$
\end{tabular}

\subsection{CONCLUSION}

The results obtained from this study showed that only Total Coliform bacteria are present when the rainwater is collected in an open space. The decreasing in the bacteria densities throughout the testing period showed that the growth of the bacteria is affected by the environmental factors that are the temperature, $\mathrm{pH}$, oxygen concentration and nutrient concentration. Therefore, the results of this study indicate that due to the limited oxygen and nutrients concentration present, as well as the limitation in the ideal range of temperature and $\mathrm{pH}$ for the growth of the bacteria, these correspond to the decreasing of bacteria densities in the collected rainwater throughout the testing period.

\section{REFERENCES}

[1] V. T. Nguyen, "Promoting Rainwater Harvesting in Vietnam Urban Areas", International Conference and Summer School 2007, Univerlagtuberlin, 2008

[2] E. Sazakli, A. Alexopoulos, and M. Leotsinidis, "Rainwater harvesting, quality assessment and utilization in Kefalonia Island, Greece", Water Research, vol. 41, no. 9, pp. 2039-47, 2007.

[3] C. Vialle, C. Sablayrolles, M. Lovera, S. Jacob, M.-C. Huau, and M. Montrejaud-Vignoles, "Monitoring of water quality from roof runoff: Interpretation using multivariate analysis", Water Research, vol. 45, no. 12, pp. 3765-75, 2011

[4] J. Y. Lee, G. Bak, and M. Han, "Quality of roof-harvested rainwater-comparison of different roofing materials", Environmental Pollution (Barking, Essex : 1987), vol. 162, pp. 422-429, 2012.

[5] G. J. Tortora, B. R. Funke, and C. L. Case, "Microbiology: An Introduction (10th ed.)", San Fransisco: Benjamin Cummings, 2010.

[6] P. G. Engelkirk, J. L. Duben-Engelkirk, and G. R. W. Burton, "Burton's Microbiology for the Health Sciences", Lippincott Williams \& Wilkins, p. 433, 2011.

[7] Y.-J. An, D. H. Kampbell, and G. P. Breidenbach, "Escherichia coli and total coliforms in water and sediments at lake marinas", Environmental Pollution, vol. 120, no. 3, pp. 771-778, 2002.

[8] M. A. Bandara, R. P. Silva', and N. D. Dayawansa, "Household Water Security through Stored Rainwater and Consumer Acceptability: A Case Study of the Anuradhapura District", Proceedings of the National Conference on Water, Food Security, and Climate Change in Sri Lanka. IWMI, 2010.

[9] J. F. Mongillo, and L. Zierdt-Warshaw, "Encyclopedia of Environmental Science”, University Rochester Press, 2000.

[10] P. Verma, "Cooling Water Treatment FAQ", Books on Water Treatment, 2004.

[11] R. I. Midwest, A. Hittman, and U. S. Office of Air and Water Programs, "Methods for identifying and evaluating the nature and extent of nonpoint sources of pollutants", Washington, D.C.: U.S. Government Printing Office, 1973.

[12] S. Srivastava, "Understanding Bacteria", Springer Science \& Business Media, vol. 30, p.469, 2003.

[13] S. Lingireddy, "Control of Microorganisms in Drinking Water", U.S.A: ASCE Publications, 2002.

[14] R. E. McKinney, "Environmental Pollution Control Microbiology: A Fifty-Year Perspective”, CRC Press, 2004.

[15] M. Fletcher, and D. C. Savage, "Bacterial Adhesion: Mechanisms and Physiological Significance”, Springer Science \& Business Media, 2013

[16] A. K. Camper, G. A. Mcfeters, W. G. Characklis, and A. W. Jones, "Growth Kinetics of Coliform Bacteria under Conditions Relevant to Drinking Water Distribution Systems", Applied And Environmental Microbiology, vol. 57, no. 8, pp. 2233-2239, 1991.

[17] J. Clement, "Influence of Distribution System Infrastructure on Bacterial Regrowth", London, U.K.: IWA Publishing, 2004.

[18] P. C. DIANE, “Control of Biofilm Growth in Drinking Water Distribution Systems", Washington, DC: DIANE Publishing, 1994.

[19] R. Narayan, S. Bose, and A. Bandyopadhyay, "Biomaterials Science: Processing, Properties and Applications II: Ceramic Transactions", John Wiley \& Sons, vol. 237, 2012

[20] Engineering Services Division, Ministry of Health Malaysia, "National Standard for Drinking Water Quality", 2004.

[21] W.H.O., "Guidelines for Drinking-water Quality", vol. 1, $3^{\text {rd }}$ Edition Incorporating $1^{\text {st }}$ and $2^{\text {nd }}$ Addenda, 2008. 